\title{
Petrogenesis of basalts for Sangxiu Formation in the central segment from Tethyan Himalayas: Plume-lithosphere interaction
}

\author{
Zhu Dicheng†*, Pan Guitang†, Mo Xuanxueł, Liao Zhongli†, Wang Liquan†, J iang Xinsheng† and Zhao Zhidan‡ \\ † Chengdu Institute of Geology and Mineral Resources, Chengdu, 610082, CHINA \\ ¥ China University of Geosciences, Beijing, 100083, CHINA \\ *To whom correspondence should be addressed.E-mail: cdzdc@cgs.gov.cn
}

\begin{abstract}
Sangxiu Formation, which is only distributed in the Yangzuoyong Tso area (south to Lhasa, Figure 1b), is a special stratum unit that is mainly characterized by volcanic interlayers. Tectonically, it is located in the eastern part of central segment of Tethyan Himalayas, and paleogeography belongs to the northern margin of Greater India. Here one finds not only the southern transitional part of space-time framework of the central-eastern Yarlung Zangbo ophiolitic mélange zone, but also the supposedly the extended end-point of Ninetyeast Ridge (Figure 1a). The age of the Sangxiu Fm is from Late Jurassic to Early Cretaceous, which is constrained by fossils, though precise isotopic age of basaltic magmatic effusion is not known at present. Regionally, the Rajmahal traps on eastern Indian margin are explained by the consequences of early activity of the Kerguelen hotspot (Kent et al. 2002), and the track of Kerguelen hotspot since 120 Ma was interpreted from Rajmahal traps via Ninetyeast Ridge to the Kerguelen hotspot (O'Neill et al. 2003). If the early volcanic activity of the Kerguelen hotspot is extended much farther to the north and northeast, can this hotspot influence the volcanic activity in Tethyan Himalayas- the northern margin of Greater India during Late Jurassic to Early Cretaceous?

The goal of this paper is to show our recent work on the geochemical and isotopic compositions and to discuss the characteristics of magmatic source, especially to shed light on the petrogenetic processes and to suggest a possible genetic relationship with Kerguelen hotspot in the light of systemically petrological and geochemical data (including REE, incompatible trace element and isotopic data) for basalts from Sangxiu Fm in Tethyan Himalayas.
\end{abstract}

\section{Stratigraphy and petrography}

The underlying stratum of Sangxiu Fm is the Late Jurassic Weimei Fm., which is mainly consists of quartz sandstones and dark grey argillaceous rocks with high content of quartz, shallow water ripple marks and relic fossils, is thought to the sedimentary records of shore-shallow sea (Jiang et al. 2003). The overlying stratum is the Early Cretaceous Jiabula Fm. that is characterized by accumulates of collapse and turbid sediments. The lower parts of Sangxiu Fm are mainly composed of apogrites, conglomerates, the middle parts are mainly basalts and shales gripped, and the upper parts are aleuritic shales and calcipulverite lens gripped. The massive, amygdaloidal, pillow basalts can be observed in different outcrops.

The phenocrysts (about 5-10\%) in basalts are mainly consist of plagioclase and pyroxene, which have experienced variable degree of alteration and metamorphism, however, the original textures appear to have been preserved; the plagioclase groundmass also underwent partly alteration; the accessory mineral assemblages include ilmenite, titanite and magnetite.

\section{Geochemistry}

The significant features of basalts from Sangxiu Fm. are characterized by high contents of $\mathrm{TiO}_{2}, \mathrm{FeO}$ and $\mathrm{P}_{2} \mathrm{O}_{5}$ (averages are $3.46 \%, 7.76 \%, 0.51 \%$ respectively) that are similar to the OIB in Hawaiian, and low content of MgO (average is only $4.64 \%$ ) indicating an evolved magma. Using the immobile trace element discrimination diagram $\left(\mathrm{Nb} / \mathrm{Y}-\mathrm{Zr} / \mathrm{TiO}_{2}\right.$, Winchester and Floyd, 1977) confirms that the basalts of Sangxiu Fm belong to alkaline basalt.
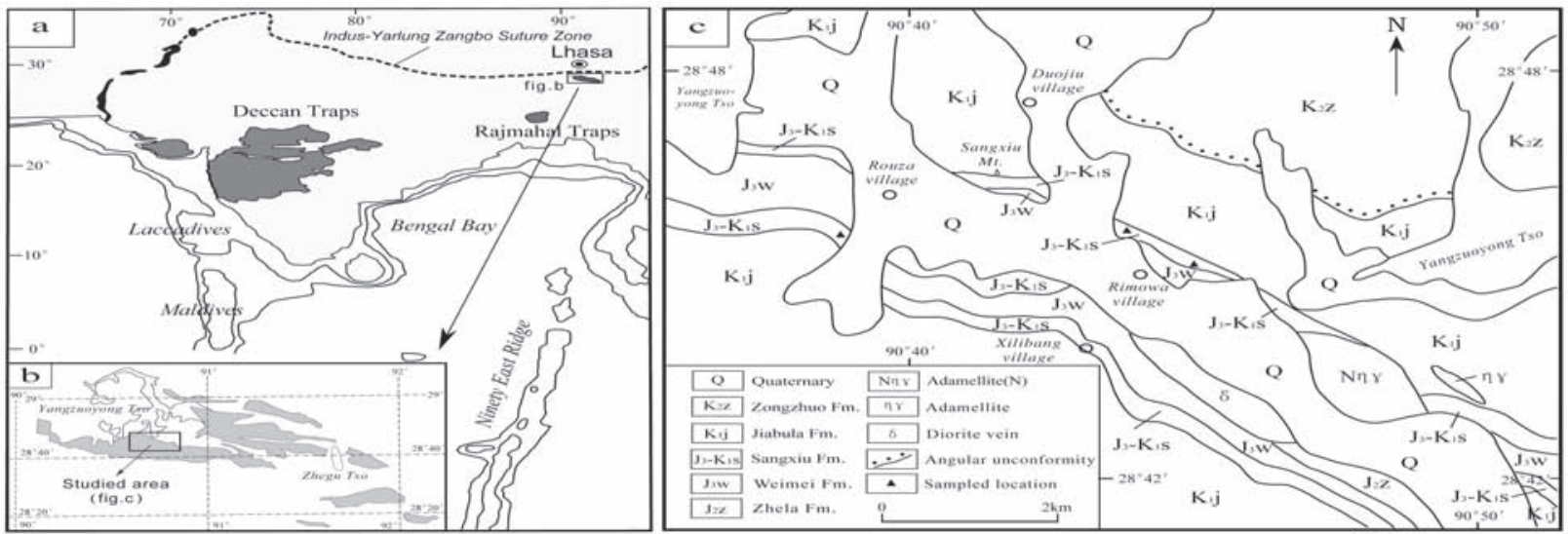

FIGURE 1. Geological distribution map for basalts from Sangxiu Formation in the central segment of Tethyan Himalayas. a. Tectonic location (modified from Mahoney et al. 2002). b. Distributions (after Pan Gui-tang et al. 2004, in press). c. Geological map for studied area (Regional Geological report (1: 250, 000) for Luoza County, 2003, unpublished) 
Geochemically, the basalts are characterized by high contents of total REE $\left(\sum \mathrm{REE}_{\text {aver }}=213.99 \times 10-6\right)$, enriched in LREE $\left[(\mathrm{La} / \mathrm{Yb})_{\text {Naver }}=8.42 \sim 10.15\right]$ and in HFSE $\left[\mathrm{Nb}_{\text {aver. }}, \mathrm{Zr}_{\text {aver }}\right.$ are $35.58 \times 10^{-6}, 352 \times 10^{-6}$ respectively], as well as in some LILE (Ba, Th etc.). All of these characteristics together with high ratios of Ti/Y (578.71 753.96), $\mathrm{Zr} / \mathrm{Y}$ (10.2 10.98), indicating a similarity with OIB. On the other hand, the basalts show lower abundances of compatible elements (such as of $\mathrm{Cr}_{\text {aver, }}, \mathrm{Yb}_{\text {aver }}$ are only $3.32 \times 10^{-6}$ and $2.86 \times 10^{-6}$ respectively), indicating a fractional crystallization and/or garnet remains in source. The markedly characteristics of the basalts are characterized by high $\mathrm{Sr}$, low $\mathrm{Nd}$ isotopic compositions, the age-corrected (150Ma assumed) of isotopic compositions of basalts for Sangxiu Fm are ranging between 0.707331 and 0.709889 for ${ }^{87} \mathrm{Sr} /{ }^{86} \mathrm{Sr}$, between 0.512364 and 0.512554 for ${ }^{143} \mathrm{Nd} /{ }^{144} \mathrm{Nd}$ respectively.

Basalts from Sangxiu Fm are more enriched in LREE and HFSE than those of tholeiites in Rajmahal and Hawaiian, which further confirm that these basalts are alkaline series. The other important features among the alkaline basalt patterns relative to the $\mathrm{N}-\mathrm{MORB}$ pattern are depletions in $\mathrm{Y}, \mathrm{Yb}$ and some of $\mathrm{Rb}$, and are enrichments in LILEs (especially in $\mathrm{Ba}, \mathrm{Th}$ ) and HFSEs. In general, these two kinds of patterns are not only largely parallel to the OIB in Hawaiian and Kerguelen, but also are similar to Rajmahal alkaline basalts, they are all plot within the field of Emeishan basalts, suggesting that the basalts of Sangxiu Fm. are most likely derived from OIB-type magma that are similar to Hawaiian and other plume-derived record.

The discrimination plots indicate that the alkaline basalts were derived from melts generated in continental margin rift environment, in agreement with the underlying stratum that was thought to the sedimentary records of shore-shallow sea.

\section{Petrogenesis}

\section{Identification of OIB-type component}

Apart from the REE and trace element patterns of basalts for Sangxiu Fm indicate that these basalts are petrogenetically related to the OIB-type magma, the following evidences further confirm that the melts are derived from OIB-type mantle source:

(i) The La/Nb-La, Nb/Th-Nb, Sm/Eu-La/Yb and Tb/Yb-La/ $\mathrm{Yb}$ diagrams are believed to the effectively diagrams to identify the characteristics of magmatic source (Li Shuguang 1993, Xu Xue-yi et al. 2003), basalts from Sangxiu Fm. are all clusteringly plot within OIB field on these diagrams, showing the source of magma has a clear similarity with OIB.

(ii) From the fuzzy cluster analyzed diagram of incompatible trace element ratios (i.e. $\mathrm{Zr} / \mathrm{Nb}, \mathrm{La} / \mathrm{Nb}, \mathrm{Ba} / \mathrm{Nb}, \mathrm{Ba} /$ $\mathrm{Th}, \mathrm{Rb} / \mathrm{Nb}$, Th/Nb, Th/La, Ba/La) for Sangxiu Fm basalts, hotspot/plume-basalts and major geochemical reservoirs, we can conclude that these basalts are akin to the hotspot-type magma inferred from the larger distance of cluster with Hawaiian basalts, Kerguelen OIBs and Ninetyeast Ridge basalts than that of $\mathrm{N}$ MORB and crust.

(iii) Furthermore, a widely accepted concept is that the isotopic ratio of $\mathrm{Nd}$ is insusceptible to alteration during metamorphism and magmatic evolution processes, the $\mathrm{Nd}$ isotopic composition represents the characteristics of magmatic source. The depleted Nd isotopic ratios of basalts for Sangxiu Fm are close to one of the OIB-type end members (EMI) also indicating an affiliation with deep mantle materials.

\section{Lithospheric component}

How to explain the high initial $\mathrm{Sr}$ isotopic composition for basalts from Sangxiu Fm? Four factors need to be considered we think: a. crustal contamination; b. alteration by seawater; c. degree of partial melting, d. contributions from lithospheric mantle. Due to the crustal contamination has been eliminated by trace element indicators, the best way to interpret the high initial $\mathrm{Sr}$ isotopic compositions for these basalts would ascribe to the results of alteration by seawater, lower degree of partial melting and contamination of lithospheric mantle materials inferred from alkaline basalt with pillow structure and low initial ratio of $\mathrm{Nd}$ isotope of basalt from Sangxiu Fm. The imprints from lithospheric mantle can also be identified by the $(\mathrm{Th} / \mathrm{Ta})_{\mathrm{PM}}-(\mathrm{La} / \mathrm{Nb})_{\mathrm{PM}}$, $(\mathrm{Th} /$ $\mathrm{Nb})_{\mathrm{PM}}-\mathrm{Nb} / \mathrm{U}$ and $\mathrm{Nb} / \mathrm{Th}-\mathrm{Ti} / \mathrm{Yb}$ diagrams, together with the fuzzy cluster of incompatible trace element ratios analyzed diagram that shows a fairly large distance of cluster with lithospheric mantle. In $\mathrm{Ce} / \mathrm{Y}-\mathrm{Zr} / \mathrm{Nb}$ diagram, the basalts of Sangxiu Fm fall between depleted garnet lherzolite (GD) and primitive garnet lherzolite (GP) non-modal fractional melting curves (Deniel C, 1998). Integrated with the high ratios of $\mathrm{Ce} / \mathrm{Yb}(=25.70 \sim 31.82)$, as well as the considerable fractionation between LREE and HREE, further confirm that the alkaline basalts of Sangxiu Fm are related to low degree of partial melting of melts from lithospheric mantle.

As discussed previously, trace element and Sr-Nd isotopic ratios provide the clearly evidences for these basalts derived from the OIB-type mantle and lithospheric mantle source. Therefore, a model of plume-lithosphere interaction is attractive for basalts from Sangxiu Fm. The basalts are interpreted as the products of lower degree of partial melting within the mixed magmas that may have formed as a result of the infiltration of plume-derived melts into the base of lithosphere, which indicating a process of plume-lithosphere interaction.

\section{Relationship to Kerguelen hotspot}

Geochemically, the characteristics of basalts from Sangxiu Fm are similar to those from Rajmahal basalts in eastern India, Ninetyeast Ridge and Kerguelen hotspot in Indian Ocean, whereas the isotopic composition of these basalts are significantly far from the fields of basalts from the Tethys and Yarlung Zangbo. Combined with the tectonic location of basalts from Sangxiu Fm, it would be relatively straightforward to explain the similar geochemical characteristics between basalts for Sangxiu Fm from the Tethyan Himalayas and basalts from the eastern Indian (Rajmahal Traps), the Ninetyeast Ridge and the Kerguelen hotspot in Indian Ocean were the consequences of interaction between the early activity of Kerguelen hotspot and lithosphere of northern margin of Greater India.

\section{Conclusions}

Basalts of Sangxiu Fmin the central segment of Tethyan Himalayas have similar geochemical characteristics to OIB, trace element and $\mathrm{Sr}-\mathrm{Nd}$ isotopic ratios provide the clearly evidences for these basalts derived from the OIB-type mantle and lithospheric mantle source. The basalts are interpreted as the products of lower degree of partial melting within the mixed magmas that may have formed as a result of the infiltration of plume-derived melts into the base of lithosphere. It would be a consequence of the interaction between early activity of Kerguelen hotspot and lithosphere in northern margin of Greater India.

\section{Acknowledgments}

This study is financially supported by the National Keystone Basic Research Program of China (no.2002CB412609) and the Key Laboratory of Lithospheric Tectonics and Exploration, China University of Geosciences, Ministry of Education, China (no.2003004). 


\section{References}

Jiang X, Y Yan and G Pan. 2004. Sedimentary environment of the Late Jurassic Weimei Formation in the southern Tibetan Tethys. Geol Bull China 22(11-12): 900-907 (in Chinese with English abstract)

Kent RW, MS Pringle, and RD Müller. 2002. ${ }^{40} \mathrm{Ar} /{ }^{39} \mathrm{Ar}$ Geochronology of the Rajmahal Basalts, India, and their Relationship to the Kerguelen Plateau. J Petro 43(7):1141-1153

Li S. 1993. Ba-Nb-Th-La diagrams used to identify tectonic environments of ophiolite. Acta Petrologic Sinica 9(2): 146-157 (in Chinese with
English abstract)

O’Neill C, D Müller and B Steinberger. 2003. Geodynamic implications of moving Indian Ocean hotspots. Earth Planet Sci Lett 215(1): 151168

Xu X, L Xia and Z Xia. 2003. Geochemistry and genesis of CretaceousPaleogene basalts from the Tuoyun Basin, southwest Tianshan mountains [J]. Geochimica 32(6): 551-560 (in Chinese with English abstract) 